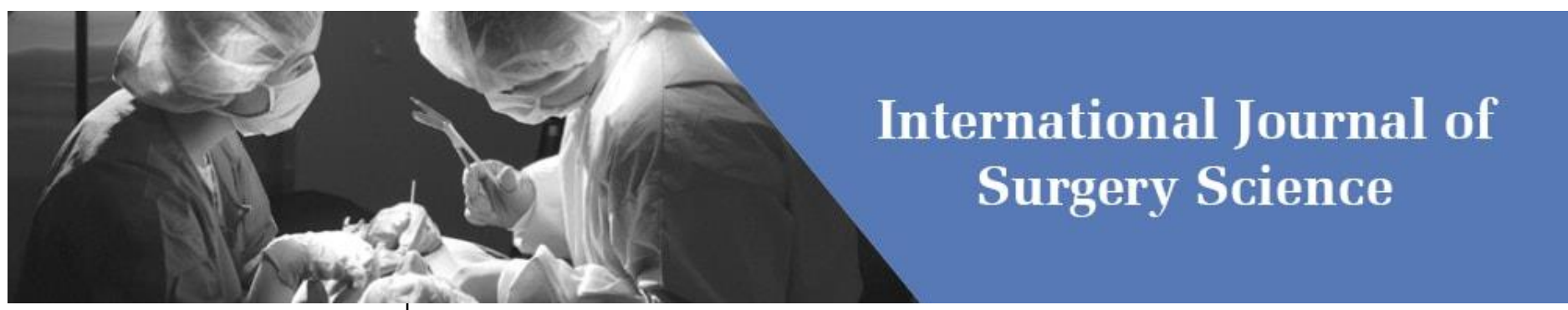

E-ISSN: 2616-3470

P-ISSN: 2616-3462

(C) Surgery Science

www.surgeryscience.com

2021; 5(1): 603-605

Received: 17-10-2020

Accepted: 29-11-2020

Dr. Harish Nayak Pangal

Associate Professor, Department of

Surgery, Srinivas Institute of

Medical Sciences, Mangalore,

Karnataka, India
Corresponding Author:

Dr. Harish Nayak Pangal

Associate Professor, Department of

Surgery, Srinivas Institute of

Medical Sciences, Mangalore,

Karnataka, India

\section{Hyponatraemia in the Surgical Patients}

\author{
Dr. Harish Nayak Pangal
}

DOI: https://doi.org/10.33545/surgery.2021.v5.i1g.642

\section{Abstract}

Hyponatremia occurs when the hypothalamic-kidney feedback loop is overwhelmed by increased fluid intake, the feedback loop malfunctions such that ADH is always "turned on", the receptors in the kidney are always "open" regardless of there being no signal from ADH to be open; or there is an increased ADH even though there is no normal stimulus (elevated serum sodium) for ADH to be increased. Sodium is the primary positively charged ion outside of the cell and cannot cross from the interstitial space into the cell. This is because charged sodium ions attract around them up to 25 water molecules, thereby creating a large polar structure too large to pass through the cell membrane: "channels" or "pumps" are required. This study is intended to help the physicians and also clinical practitioners to identify and also help the patients so as to stall the always fatal outcome if treatment is delayed.

Keywords: Clinical, management profile, Hyponatraemia

\section{Introduction}

Hyponatremia occurs when the hypothalamic-kidney feedback loop is overwhelmed by increased fluid intake, the feedback loop malfunctions such that ADH is always "turned on", the receptors in the kidney are always "open" regardless of there being no signal from ADH to be open; or there is an increased ADH even though there is no normal stimulus (elevated serum sodium) for ADH to be increased. Sodium is the primary positively charged ion outside of the cell and cannot cross from the interstitial space into the cell. This is because charged sodium ions attract around them up to 25 water molecules, thereby creating a large polar structure too large to pass through the cell membrane: "channels" or "pumps" are required. Cell swelling also produces activation of volume-regulated anion channels which is related to the release of taurine and glutamate from astrocytes.

A serum level of less than $135 \mathrm{mmol} / \mathrm{lit}$ is defined as hyponatraemia. It can be due to be either hypervolemia, euvolemia or hyporvolemia condition ${ }^{[1,2,3]}$. It has a high prevalence especially with patients with metabolic disorders ${ }^{[4,5]}$. Diabetes is one such condition. Over correction of dehydration is the leading cause of the illness. Acute is a state where the whole scenario arises and manifests within 48 hours. Hyponatremia causes neurological deficits and the patients come with a plethora of symptoms. Pinpoint diagnosis is the need of the hour as any delay in identifying can actually cause fatal irreversible brain damage to the patients [6, 7, 8]. The correction also if identified has to be done in a graded manner, if not may again be fatal by causing osmotic demyelination ${ }^{[8]}$.

This study puts in an effort to study the clinical and management profile of hyponatraemia cases. This study is intended to help the physicians and also clinical practitioners to identify and also help the patients so as to stall the always fatal outcome if treatment is delayed.

\section{Aims and Objectives}

To study the hyponatraemia cases in the Department of Surgery.

\section{Materials and Methods}

This is a retrospective study. Which was conducted from Feb 2017 - January 2019 in the Department of Surgery, Srinivas Institute of Medical Sciences, Mangalore.

Eleven cases who were posted in the Department were the sample size taken for the study.

Inclusion Criteria: Paatients who had clinical symptoms and were posted for surgery. 


\section{Exclusion Criteria}

No Consent from the patients side Patients who are on hypernatremia causing drugs

All the statistical Analysis was done using latest SPSS software 2015 California.

The grading of the hyponatremia is as follows. Mild is defined as serum level in the range of $125 \mathrm{Eq} / \mathrm{lit}$ to $134 \mathrm{mEq} / \mathrm{lit}$. Moderate Hyponatraemia is defined as serum levels between $125 \mathrm{mEq} / \mathrm{L}$ - $129 \mathrm{mEq} / \mathrm{L}$, and Severe Hyponatraemiais defined as less than $124 \mathrm{mEq} / \mathrm{lit}$. The treatment should never be corrected more than $25 \mathrm{mEq} /$ lit over 24 hours ${ }^{[9,10]}$.

\section{Results}

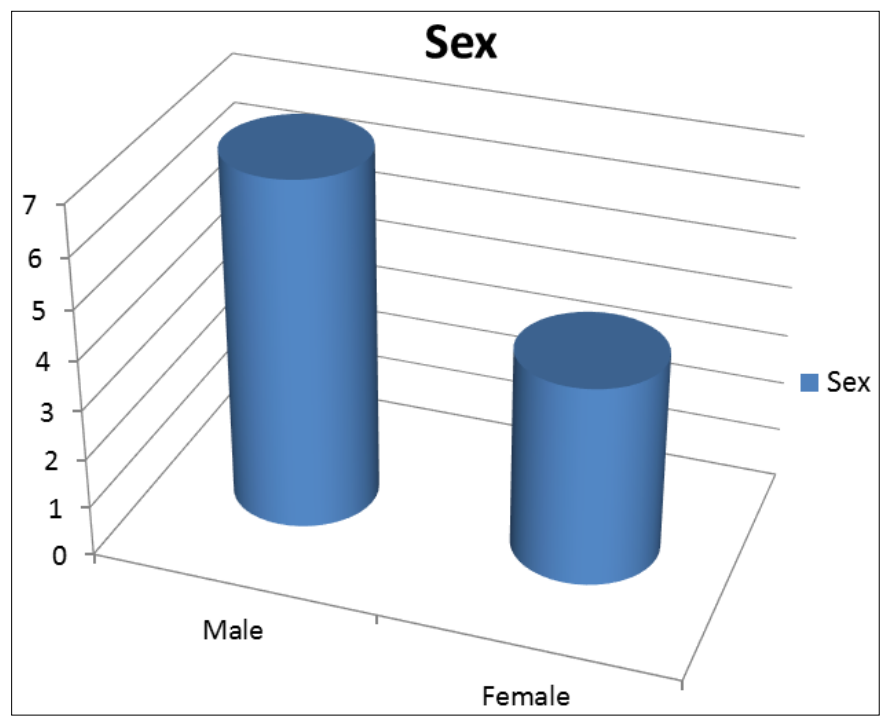

Fig 1: Sex Distribution

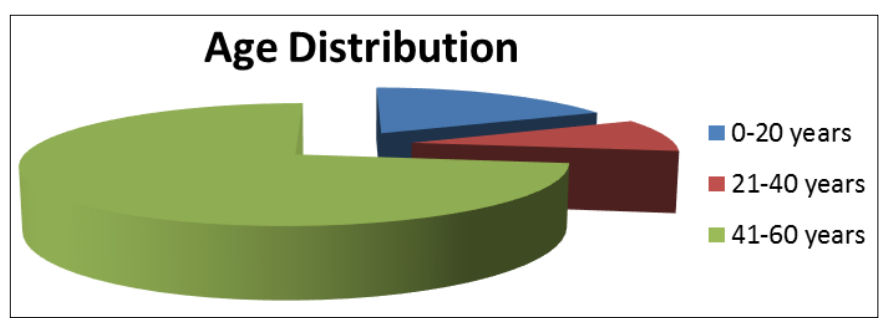

Fig 2: Age Distribution

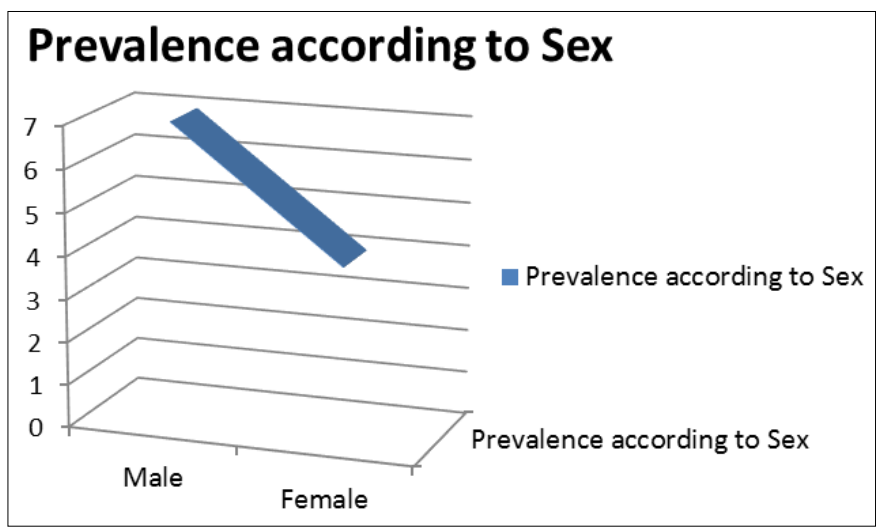

Fig 3: Male and Female Prevalence

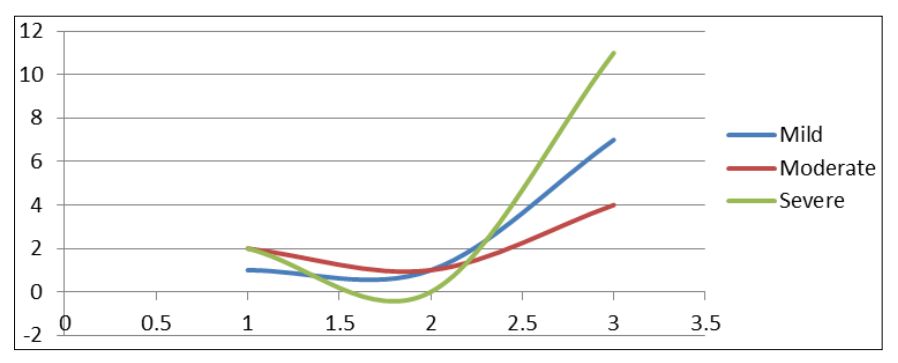

Fig 4: Severity

Table 1: Clinical Symptoms

\begin{tabular}{|c|c|c|}
\hline Symptoms & Male & Female \\
\hline Disorientation & 3 & 1 \\
\hline Hiccups & 1 & 1 \\
\hline Vomiting & 2 & 1 \\
\hline Nausea & 6 & 1 \\
\hline Confusion & 7 & 2 \\
\hline Oedema & 1 & 3 \\
\hline Convulsion & 1 & 1 \\
\hline Anorexia & 2 & 1 \\
\hline
\end{tabular}

Table 2: Treatment

\begin{tabular}{|c|c|c|}
\hline Treatment & Duration & Complication \\
\hline $\begin{array}{c}3 \% \text { saline, IV fluids, fluid } \\
\text { restriction }\end{array}$ & 3.14 days & $\begin{array}{c}1 \text { people with } \\
\text { Sequale }\end{array}$ \\
\hline
\end{tabular}

\section{Discussion}

Hyponatremia is a low sodium concentration in the blood. It is generally defined as a sodium concentration of less than $135 \mathrm{mmol} / \mathrm{L}(135 \mathrm{mEq} / \mathrm{L})$, with severe hyponatremia being below $120 \mathrm{mEq} / \mathrm{L}$. Symptoms can be absent, mild or severe. Mild symptoms include a decreased ability to think, headaches, nausea, and poor balance. Severe symptoms include confusion, seizures, and coma.

The causes of hyponatremia are typically classified by a person's body fluid status into low volume, normal volume, or high volume. Low volume hyponatremia can occur from diarrhea, vomiting, diuretics, and sweating. Normal volume hyponatremia is divided into cases with dilute urine and concentrated urine. Cases in which the urine is dilute include adrenal insufficiency, hypothyroidism, and drinking too much water or too much beer. Cases in which the urine is concentrated include syndrome of inappropriate antidiuretic hormone secretion (SIADH). High volume hyponatremia can occur from heart failure, liver failure, and kidney failure. Conditions that can lead to falsely low sodium measurements include high blood protein levels such as in multiple myeloma, high blood fat levels, and high blood sugar.

Treatment is based on the underlying cause. Correcting hyponatremia too quickly can lead to complications. Rapid partial correction with $3 \%$ normal saline is only recommended in those with significant symptoms and occasionally those in whom the condition was of rapid onset. Low volume hyponatremia is typically treated with intravenous normal saline. SIADH is typically treated by correcting the underlying cause and with fluid restriction while high volume hyponatremia is typically treated with both fluid restriction and a diet low in salt. Correction should generally be gradual in those in whom 
the low levels have been present for more than two days.

Hyponatremia is the most common type of electrolyte imbalance. It occurs in about $20 \%$ of those admitted to hospital and $10 \%$ of people during or after an endurance sporting event. Among those in hospital, hyponatremia is associated with an increased risk of death. The economic costs of hyponatremia are estimated at $\$ 2.6$ billion in the United States.

\section{Conclusion}

The surgeon should be in a position to diagnose the condition immediately and treat promptly and effectively. This is a very dangerous condition and the surgeons should be vigilant of these conditions.

\section{References}

1. Taal MW, Yu ASL, Chertow GM et al. Brenner \& Rector's the kidney. 9th Edn. Philadelphia, PA: Elsevier Saunders 2012.

2. Coffman TM, Falk RJ, Molitoris BA. Schrier's diseases of the kidney. 9th Edn. Philadelphia: Wolters Kluwer/Lippincott Williams \& Wilkins 2013.

3. Johnson RJ, Feehally J, Floege J. Comprehensive clinical nephrology. 5th edn. Philadelphia, PA: Elsevier Saunders 2015, pp1320.

4. Hawkins RC. Age and gender as risk factors for hyponatraemia and hypernatraemia. Clin Chim Acta 2003;337(1-2):169-172.

5. Upadhyay A, Jaber BL, Madias NE. Incidence and prevalence of hyponatraemia. Am J Med 2006;119(7/1):S30-S35.

6. Fraser CL, Arieff AI. Epidemiology, pathophysiology, and management of hyponatraemic encephalopathy. Am J Med 1997;102(1):67-77.

7. Kamel KS, Halperin ML. Managing overly rapid correction of chronic hyponatraemia: an ounce of prevention or a pound of cure? Canada J Am Soc. Nephrol 2010;21(12):2015-2016.

8. Murase T, Sugimura Y, Takefuji S, et al. Mechanisms and therapy of osmotic demyelination. Am J Med 2006;119(7 Suppl 1):S69-S73.

9. Sterns RH, Nigwekar SU, Hix JK. The treatment of hyponatraemia. Semin Nephrol 2009;29(3):282-299.

10. Waikar SS, Mount DB, Curhan GC et al. Mortality after hospitalization with mild, moderate, and severe hyponatraemia. Am J Med 2009;122(9):857-865. 